\title{
Silver complexes of 1,2,4-triazole derived N-heterocyclic carbenes: Synthesis, structure and reactivity studies
}

\author{
CHANDRAKANTA DASH ${ }^{\mathrm{a}}$, MOBIN M SHAIKH ${ }^{\mathrm{b}}$ and PRASENJIT GHOSH ${ }^{\mathrm{a}, *}$

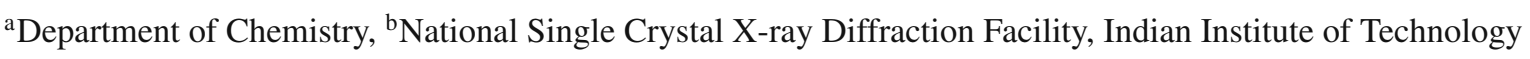 \\ Bombay, Powai, Mumbai 400 076, India \\ e-mail:pghosh@chem.iitb.ac.in
}

\begin{abstract}
Two silver(I) complexes $\left\{\left[1-\mathrm{R}-4-(N \text { - } t \text {-butylacetamido)-1,2,4-triazol-5-ylidene }]_{2} \mathrm{Ag}\right\}^{+} \mathrm{Cl}^{-}[\mathrm{R}=\mathrm{Et}\right.$ (1b), $i$ - $\operatorname{Pr}(\mathbf{2 b})]$ of $N / O$-functionalized $N$-heterocyclic carbenes derived from 1,2,4-triazoles are reported. The silver complexes, $\mathbf{1 b}$ and $\mathbf{2 b}$, have been synthesized from the reaction of the $N / O$-functionalized triazolium chloride salts namely, 1-R-4-( $N$ - $t$-butylacetamido)-1,2,4-triazolium chloride $[\mathrm{R}=\mathrm{Et}(\mathbf{1 a}), i$-Pr $(\mathbf{2 a})]$ by treatment with $\mathrm{Ag}_{2} \mathrm{O}$ in 53-56\% yield. The 1,2,4-triazolium chloride salts $1 \mathbf{a}$ and $2 \mathbf{a}$ were prepared by the alkylation reaction of 1-R-1,2,4-triazole ( $\mathrm{R}=\mathrm{Et}, i$-Pr) with $N$ - $t$-butyl-2-chloro acetamide in $47-63 \%$ yield. The molecular structures of the silver(I) complexes, $\mathbf{1 b}$ and $\mathbf{2} \mathbf{b}$, have been determined by X-ray diffraction studies. The density functional theory studies on the silver $\mathbf{1 b}$ and $\mathbf{2 b}$ complexes suggest that the 1,2,4-triazole derived $\mathrm{N}$-heterocyclic carbenes to be strong $\sigma$-donating ligands similar to the now much recognized imidazolebased $\mathrm{N}$-heterocyclic carbenes. The reactivity studies with $\left(\mathrm{SMe}_{2}\right) \mathrm{AuCl}$ and $\left(\mathrm{SMe}_{2}\right) \mathrm{CuBr}$ indicated the silver complexes, $\mathbf{1} \mathbf{b}$ and $\mathbf{2} \mathbf{b}$, to be good transmetallating agents.
\end{abstract}

Keywords. Carbenes; silver; 1,2,4-triazole; crystal structure; reactivity.

\section{Introduction}

With the imidazole-based N-heterocyclic carbenes $(\mathrm{NHCs})^{1}$ showing exceptional performances in the catalysis of many important transformation, the need for expanding the scope of $\mathrm{N}$-heterocyclic carbenes to that derived from other heterocycles thus becomes obvious. In this regard, quite a few promising reports of the use of benzothiazole, ${ }^{2}$ 1,2,4-triazole, ${ }^{3}$ 1,2,3-triazole ${ }^{4}$ and pyrazole ${ }^{5}$ based $\mathrm{N}$-heterocyclic carbenes in Heck, Suzuki, Sonogashira, transfer hydrogenation and reductive amination reactions have appeared lately. The primary challenge in migrating to N-heterocyclic carbene ligands derived from other heterocycles lies in their ability to stabilize the singlet state and consequently, these N-heterocyclic carbenes are much less common compared to the imidazole-based ones. As the other hetrocycle derived N-heterocyclic carbenes offer different steric and electronic environments around the metal center, which may be gainfully used in catalysis,

*For correspondence we became interested in looking into the chemistry of 1,2,4-triazole-based $\mathrm{N}$-heterocyclic carbenes, that have so far remained less explored compared to the imidazole-based counterparts.

In particular, we remain committed to advancing the chemistry of $\mathrm{N} / \mathrm{O}$-functionalized $\mathrm{N}$-heterocyclic carbenes ${ }^{6}$ particularly by exploring their utility in various catalytic transformations as well as in biomedical applications. ${ }^{7}$ In this regard, we have investigated the chemistry of imidazole-based N-heterocyclic carbene complexes of transition metals for various types of palladium mediated $\mathrm{C}-\mathrm{C}$ cross coupling reactions like Suzuki, ${ }^{8}$ Hiyama ${ }^{9}$ and Sonogashira couplings. ${ }^{9,10} \mathrm{We}$ also reported various nickel bifunctional precatalysts for the base-free Michael addition reactions ${ }^{11}$ and the silver and gold-based ones for producing biodegradable polymers by the ring-opening polymerization (ROP) of L-lactide. ${ }^{12}$ In addition, we also explored the utility of the metal complexes of the imidazole-based $\mathrm{N}$ heterocyclic carbenes for a variety of biomedical applications in the form of anticancer and antimicrobial studies. ${ }^{7}$ Having studied various facets of the imidazole-based N-heterocyclic carbene chemistry pertaining to their utility in chemical catalysis and biomedical applications, we decided to extend the 


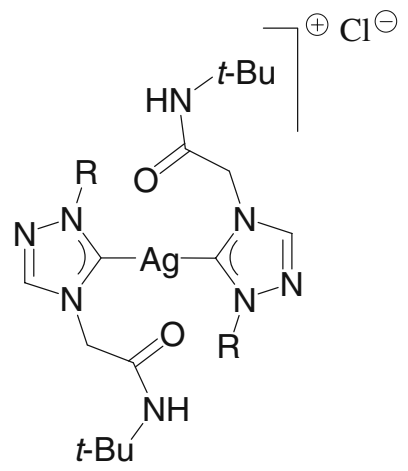

$\mathrm{R}=\mathrm{Et}(\mathbf{1 b}), i-\operatorname{Pr}(\mathbf{2} \mathbf{b})$

Figure 1. Silver complexes of 1,2,4-triazole based Nheterocyclic carbenes.

scope of our investigation to other heterocycle derived N-heterocyclic carbenes, particularly that of the 1,2,4triazole based ones, for their utility in chemical catalysis and biomedical applications.

In this contribution, we report the synthesis, structures and the reactivity studies of a series of new silver(I) complexes, $\mathbf{1 b}$ and $\mathbf{2 b}$, of 1,2,4-triazole derived $\mathrm{N}$-heterocyclic carbenes (figure 1 and scheme 1) and demonstrate their utility as potential transmetallating agents for synthesizing the copper and gold complexes (scheme 2).

\section{Experimental section}

General procedures: All reactions were carried out using standard Schlenk techniques. Solvents were purified and degassed by standard procedures. 1-i-propyl-1,2,4-triazole, ${ }^{13}$ 1-ethyl-1,2,4-triazole, ${ }^{14}$ $\left(\mathrm{SMe}_{2}\right) \mathrm{AuCl}^{15}$ and $\left(\mathrm{SMe}_{2}\right) \mathrm{CuBr}^{16}$ were synthesized according to modified literature procedures. ${ }^{1} \mathrm{H}$ and ${ }^{13} \mathrm{C}\left\{{ }^{1} \mathrm{H}\right\}$ NMR spectra were recorded in $\mathrm{CDCl}_{3}$ on a Varian $400 \mathrm{MHz}$ NMR spectrometer. ${ }^{1} \mathrm{H}$ NMR peaks are labelled as singlet (s), doublet (d), triplet (t), multiplet $(\mathrm{m})$, and septet (sept). Infrared spectra were recorded on a Perkin Elmer Spectrum One FT-IR spectrometer. Mass spectrometry measurements were done on a Micromass Q-Tof spectrometer. Elemental Analysis was carried out on Thermo Quest FLASH 1112 SERIES (CHNS) Elemental Analyzer. X-ray diffraction data for compounds $\mathbf{1 b}$ and $\mathbf{2 b}$ were collected on an Oxford Diffraction XCALIBUR-S diffractometer and crystal data collection and refinement parameters aresummarized in table 1 . The structures were solved using direct methods and standard difference map tech- niques, and were refined by full-matrix least-squares procedures on $F^{2}$ with SHELXTL (Version 6.10). ${ }^{17}$

\subsection{Synthesis of 1-(ethyl)-4-(N-t-butylacetamido)- 1,2,4-triazolium bromide (1a)}

A mixture of 1-(ethyl)-1,2,4-triazole $\quad(1.02 \mathrm{~g}$, $10.5 \mathrm{mmol})$ and $\mathrm{N}-t$-butyl-2-chloroacetamide $(1.57 \mathrm{~g}$, $10.5 \mathrm{mmol})$ in acetonitrile $(c a .5 \mathrm{~mL})$ was refluxed for $8 \mathrm{~h}$ at which the mixture turned viscous. The reaction mixture was cooled to room temperature, washed in hot hexane $(c a .2 \times 20 \mathrm{~mL})$ and dried under vacuum to obtain the product 1a as a brown viscous liquid $(1.63 \mathrm{~g}, 63 \%) .{ }^{1} \mathrm{H} \mathrm{NMR}\left(\mathrm{CDCl}_{3}, 400 \mathrm{MHz}, 25^{\circ} \mathrm{C}\right): \delta$ 10.9 (s, $1 \mathrm{H}, \mathrm{N}-\mathrm{C}(5) H-\mathrm{N}), 8.79$ (s, $1 \mathrm{H}, \mathrm{N}-\mathrm{C}(3) H-\mathrm{N})$, 8.42 (br, $1 \mathrm{H}, \mathrm{NH}), 5.42\left(\mathrm{~s}, 2 \mathrm{H}, \mathrm{CH}_{2}\right), 4.52(\mathrm{q}, 2 \mathrm{H}$, $\left.{ }^{3} J_{H H}=7 \mathrm{~Hz}, \mathrm{CH}_{2} \mathrm{CH}_{3}\right), 1.65\left(\mathrm{t}, 3 \mathrm{H},{ }^{3} J_{H H}=7 \mathrm{~Hz}\right.$, $\left.\mathrm{CH}_{2} \mathrm{CH}_{3}\right), 1.37$ (s, 9H, $\left.\mathrm{C}\left(\mathrm{CH}_{3}\right)_{3}\right) .{ }^{13} \mathrm{C}\left\{{ }^{1} \mathrm{H}\right\} \quad \mathrm{NMR}$ $\left(\mathrm{CDCl}_{3}, 100 \mathrm{MHz}, 25^{\circ} \mathrm{C}\right): \delta 163.1(\mathrm{CO}), 145.0(\mathrm{~N}-$ $C(5) \mathrm{H}-\mathrm{N}), 142.6(\mathrm{~N}-C(3) \mathrm{H}-\mathrm{N}), 51.9\left(\mathrm{CH}_{2}\right), 50.1$ $\left(\mathrm{CH}_{2} \mathrm{CH}_{3}\right), 48.1 \quad\left(\mathrm{C}_{\left.\left(\mathrm{CH}_{3}\right)_{3}\right),} 28.4\left(\mathrm{C}_{(\mathrm{CH}}\right)_{3}\right), 13.9$ $\left(\mathrm{CH}_{2} \mathrm{CH}_{3}\right)$. IR data $\left(\mathrm{cm}^{-1}\right)$ neat: $1682(\mathrm{~s})\left(v_{\mathrm{CONH}}\right)$.

\subsection{Synthesis of $\{[1-($ ethyl $)-4-(N$-t-butylacetamido $)-$ 1,2,4-triazol-5-ylidene $]_{2} \mathrm{Ag}^{+} \mathrm{Cl}^{-}(\mathbf{1 b})$}

A mixture of 1-(ethyl)-4-( $N$ - $t$-butylacetamido)-1,2,4triazolium chloride $1 \mathrm{a}(0.598 \mathrm{~g}, 2.42 \mathrm{mmol})$ and $\mathrm{Ag}_{2} \mathrm{O}$ $(0.281 \mathrm{~g}, 1.21 \mathrm{mmol})$ in dichloromethane $(c a .40 \mathrm{~mL})$, was stirred at room temperature for $4 \mathrm{~h}$. The reaction mixture was filtered and the solvent was removed under vacuum to give the product $\mathbf{1 b}$ as a brown solid $(0.364 \mathrm{~g}, 53 \%)$. Single crystals for X-ray diffraction studies was grown from the mixture of choroform and acetonitrile employing slow evaporation. ${ }^{1} \mathrm{H}$ NMR $\left(\mathrm{CDCl}_{3}, 400 \mathrm{MHz}, 25^{\circ} \mathrm{C}\right): \delta 8.44(\mathrm{br}, 2 \mathrm{H}$, $\mathrm{NH}), 8.40(\mathrm{~s}, 2 \mathrm{H}, \mathrm{N}-\mathrm{C}(3) H-\mathrm{N}), 5.24\left(\mathrm{~s}, 4 \mathrm{H}, \mathrm{CH}_{2}\right)$, $4.36\left(\mathrm{q}, 4 \mathrm{H},{ }^{3} J_{H H}=7 \mathrm{~Hz}, \mathrm{CH}_{2} \mathrm{CH}_{3}\right), 1.54(\mathrm{t}, 6 \mathrm{H}$, $\left.{ }^{3} J_{H H}=7 \mathrm{~Hz}, \mathrm{CH}_{2} \mathrm{CH}_{3}\right), 1.36\left(\mathrm{~s}, 18 \mathrm{H}, \mathrm{C}\left(\mathrm{CH}_{3}\right)_{3}\right)$. ${ }^{13} \mathrm{C}\left\{{ }^{1} \mathrm{H}\right\} \mathrm{NMR}\left(\mathrm{CDCl}_{3}, 100 \mathrm{MHz}, 25^{\circ} \mathrm{C}\right): \delta 181.7(\mathrm{Ag}-$ $\mathrm{NCN}), 165.2(C \mathrm{O}), 143.6(\mathrm{~N}-C(3) \mathrm{H}-\mathrm{N}), 51.8\left(\mathrm{CH}_{2}\right)$, $51.7\left(\mathrm{CH}_{2} \mathrm{CH}_{3}\right), 49.0\left(\mathrm{C}\left(\mathrm{CH}_{3}\right)_{3}\right), 28.6\left(\mathrm{C}\left(\mathrm{CH}_{3}\right)_{3}\right)$, $15.8\left(\mathrm{CH}_{2} \mathrm{CH}_{3}\right)$. IR data $\left(\mathrm{cm}^{-1}\right) \mathrm{KBr}$ pellet: 1674 (s) ( $v_{\text {CONH }}$ ). Anal. Calcd. for $\mathrm{C}_{20} \mathrm{H}_{36} \mathrm{~N}_{8} \mathrm{O}_{2} \mathrm{AgCl} \cdot \mathrm{CH}_{2} \mathrm{Cl}_{2}$ : C, 38.88; H, 5.90; N, 17.27. Found: C, 38.25; H, 5.89; $\mathrm{N}, 16.75 \%$.

\subsection{Synthesis of 1-(i-propyl)-4-(N-t-butylacetamido)-} 1,2,4-triazolium bromide (2a)

A mixture of 1-( $i$-propyl)-1,2,4-triazole $(0.985 \mathrm{~g}$, $8.87 \mathrm{mmol}$ ) and $\mathrm{N}-t$-butyl-2-chloroacetamide $(1.33 \mathrm{~g}$, 


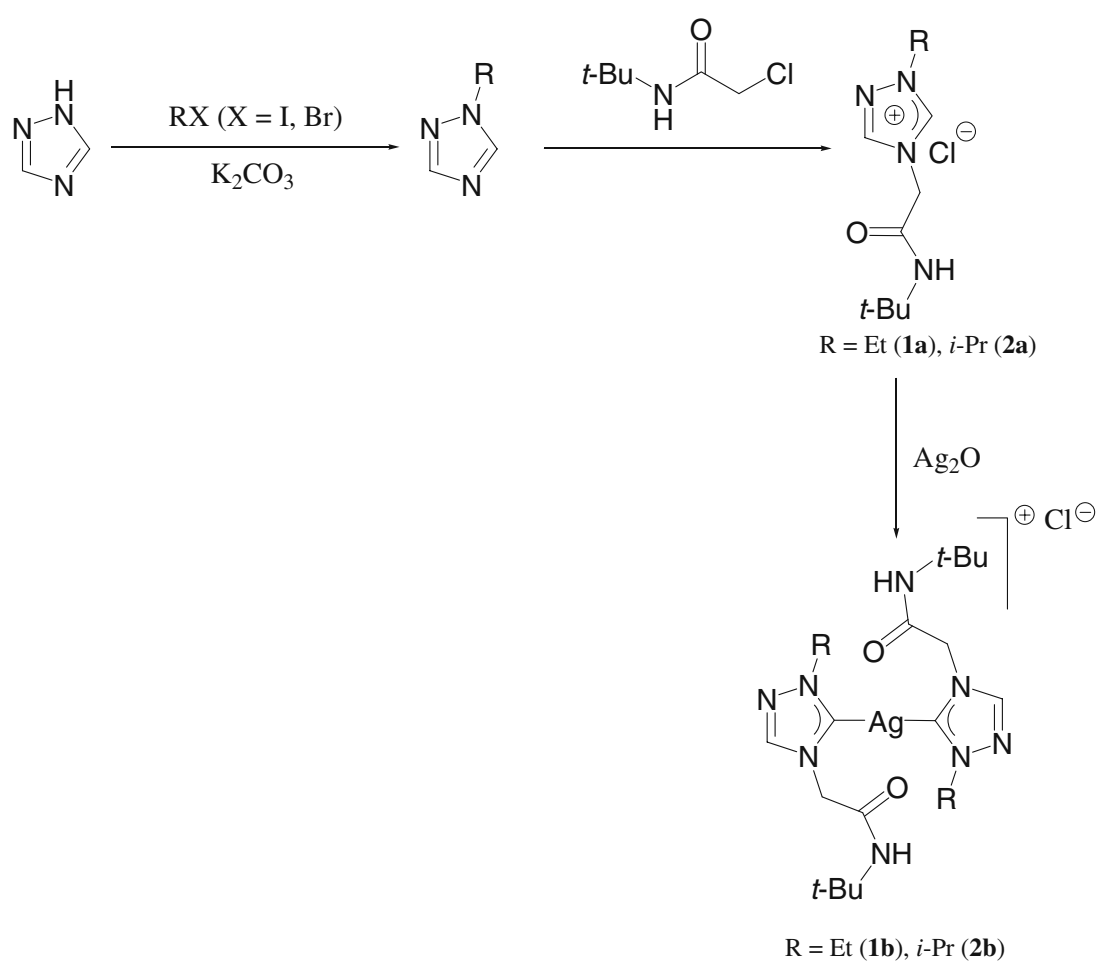

Scheme 1.

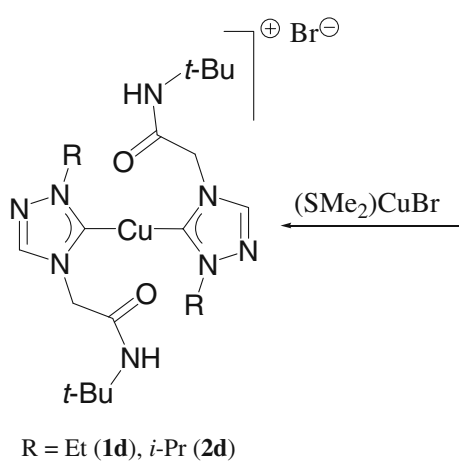

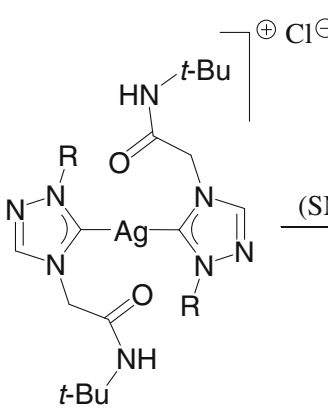

$\mathrm{R}=\mathrm{Et}(\mathbf{1} \mathbf{b}), i-\operatorname{Pr}(\mathbf{2} \mathbf{b})$

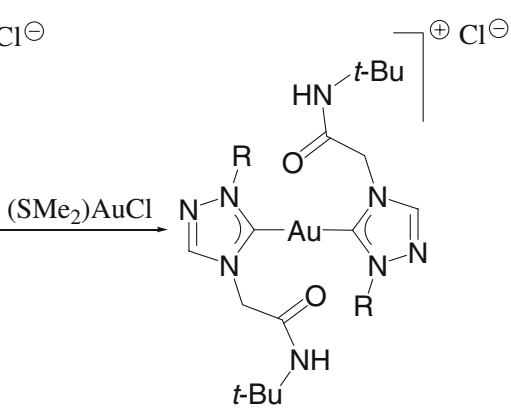

$\mathrm{R}=\mathrm{Et}(\mathbf{1 c}), i-\operatorname{Pr}(\mathbf{2 c})$

Scheme 2.

$8.87 \mathrm{mmol})$ in acetonitrile $(c a .5 \mathrm{~mL}$ ) was refluxed for $8 \mathrm{~h}$ at which the mixture turned viscous. The reaction mixture was cooled to room temperature, washed in hot hexane $(c a .2 \times 20 \mathrm{~mL})$ and dried under vacuum to give the product $2 \mathbf{a}$ as a brown viscous liquid $(1.08 \mathrm{~g}, 47 \%) .{ }^{1} \mathrm{H}$ NMR $\left(\mathrm{CDCl}_{3}, 400 \mathrm{MHz}\right.$, $\left.25^{\circ} \mathrm{C}\right): \delta 10.7(\mathrm{~s}, 1 \mathrm{H}, \mathrm{N}-\mathrm{C}(5) H-\mathrm{N}), 8.92(\mathrm{~s}, 1 \mathrm{H}, \mathrm{N}-$ $\mathrm{C}(3) H-\mathrm{N}), 8.46(\mathrm{br}, 1 \mathrm{H}, \mathrm{NH}), 5.41\left(\mathrm{~s}, 2 \mathrm{H}, \mathrm{CH}_{2}\right)$, 4.93 (sept, $\left.1 \mathrm{H},{ }^{3} J_{H H}=7 \mathrm{~Hz}, \mathrm{CH}\left(\mathrm{CH}_{3}\right)_{2}\right), 1.65$ (d, $\left.6 \mathrm{H},{ }^{3} \mathrm{~J}_{\mathrm{HH}}=7 \mathrm{~Hz}, \mathrm{CH}\left(\mathrm{CH}_{3}\right)_{2}\right), 1.36\left(\mathrm{~s}, 9 \mathrm{H}, \mathrm{C}\left(\mathrm{CH}_{3}\right)_{3}\right)$. ${ }^{13} \mathrm{C}\left\{{ }^{1} \mathrm{H}\right\} \mathrm{NMR}\left(\mathrm{CDCl}_{3}, 100 \mathrm{MHz}, 25^{\circ} \mathrm{C}\right): \delta 163.0(\mathrm{CO})$, $144.7(\mathrm{~N}-C(5) \mathrm{H}-\mathrm{N}), 141.5(\mathrm{~N}-C(3) \mathrm{H}-\mathrm{N}), 55.9\left(\mathrm{CH}_{2}\right)$,

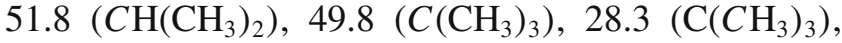
$21.4\left(\mathrm{CH}\left(\mathrm{CH}_{3}\right)_{2}\right)$. IR data $\left(\mathrm{cm}^{-1}\right)$ neat: 1682 (s) $\left(v_{\mathrm{CONH}}\right)$. HRMS (ES): m/z $225.1710[(\mathrm{NHC})+\mathrm{H}]^{+}$, Calcd. 225.1715.

2.4 Synthesis of $\{[1-(i-p r o p y l)-4-$

(N-t-butylacetamido)-1,2,4-triazol-5-

ylidene $]_{2} \mathrm{Ag}^{+} \mathrm{Cl}^{-}(\mathbf{2 b})$

A mixture of 1-( $i$-propyl)-4-( $N$-t-butylacetamido)1,2,4-triazolium chloride $2 \mathrm{a}(0.598 \mathrm{~g}, 2.43 \mathrm{mmol})$ and 
Table 1. X-ray crystallographic data for $\mathbf{1 b}$ and $\mathbf{2 b}$.

\begin{tabular}{|c|c|c|}
\hline Compound & $\mathbf{1 b}$ & $2 \mathrm{~b}$ \\
\hline Lattice & Triclinic & Triclinic \\
\hline Formula & $\mathrm{C}_{20} \mathrm{H}_{36} \mathrm{~N}_{8} \mathrm{O}_{2} \mathrm{AgCl}$ & $\mathrm{C}_{22} \mathrm{H}_{40} \mathrm{~N}_{8} \mathrm{O}_{2} \mathrm{AgCl}$ \\
\hline Formula weight & 563.89 & 591.94 \\
\hline Space group & P-1 & $\mathrm{P}-1$ \\
\hline $\mathrm{a} / \AA$ & $10.424(3)$ & $10.9812(18)$ \\
\hline $\mathrm{b} / \AA$ & $12.255(3)$ & $12.154(3)$ \\
\hline $\mathrm{c} / \AA$ & $12.893(3)$ & $13.345(4)$ \\
\hline$\alpha /^{\circ}$ & $62.64(3)$ & $115.73(3)$ \\
\hline$\beta /^{\circ}$ & $77.52(2)$ & 89.891(18) \\
\hline$\gamma /{ }^{\circ}$ & $75.69(2)$ & $108.809(18)$ \\
\hline $\mathrm{V} / \AA^{3}$ & $1407.4(6)$ & $1498.8(6)$ \\
\hline $\mathrm{Z}$ & 2 & 2 \\
\hline Temperature (K) & $120(2)$ & $150(2)$ \\
\hline $\operatorname{Radiation}(\lambda, \AA)$ & 0.71073 & 0.71073 \\
\hline$\rho$ (calcd.), $\mathrm{g} \mathrm{cm}^{-3}$ & 1.331 & 1.312 \\
\hline$\mu(\operatorname{Mo~K} \alpha), \mathrm{mm}^{-1}$ & 0.840 & 0.792 \\
\hline$\theta$ max, deg. & 25.00 & 25.00 \\
\hline No. of data & 4919 & 5227 \\
\hline No. of parameters & 297 & 317 \\
\hline $\mathrm{R}_{1}$ & 0.0781 & 0.0532 \\
\hline$w \mathrm{R}_{2}$ & 0.1874 & 0.1171 \\
\hline GOF & 0.948 & 1.091 \\
\hline
\end{tabular}

$\mathrm{Ag}_{2} \mathrm{O}(0.281 \mathrm{~g}, 1.21 \mathrm{mmol})$ in dichloromethane (ca. $30 \mathrm{~mL}$ ), was stirred at room temperature for $4 \mathrm{~h}$. The reaction mixture was filtered and the solvent was removed under vacuum to give the product $\mathbf{2 b}$ as a brown solid $(0.398 \mathrm{~g}, 56 \%)$. Single crystals for Xray diffraction studies were grown from the mixture of dichloromethane and acetonitrile employing slow evaporation. ${ }^{1} \mathrm{H} \mathrm{NMR}\left(\mathrm{CDCl}_{3}, 400 \mathrm{MHz}, 25^{\circ} \mathrm{C}\right)$ : $\delta 8.36(\mathrm{~s}, 2 \mathrm{H}, \mathrm{N}-\mathrm{C}(3) H-\mathrm{N}), 8.30(\mathrm{br}, 2 \mathrm{H}, \mathrm{NH})$, $5.10\left(\mathrm{~s}, 4 \mathrm{H}, \mathrm{CH}_{2}\right), 4.88$ (sept, $2 \mathrm{H},{ }^{3} J_{H H}=7 \mathrm{~Hz}$, $\left.\mathrm{CH}\left(\mathrm{CH}_{3}\right)_{2}\right), 1.54\left(\mathrm{~d}, 12 \mathrm{H},{ }^{3} J_{H H}=7 \mathrm{~Hz}, \mathrm{CH}\left(\mathrm{CH}_{3}\right)_{2}\right)$, 1.35 (s, $\left.18 \mathrm{H}, \mathrm{C}\left(\mathrm{CH}_{3}\right)_{3}\right) \cdot{ }^{13} \mathrm{C}\left\{{ }^{1} \mathrm{H}\right\}$ NMR $\left(\mathrm{CDCl}_{3}\right.$, $\left.100 \mathrm{MHz}, 25^{\circ} \mathrm{C}\right): \delta 180.7(\mathrm{Ag}-\mathrm{NCN}), 165.3(\mathrm{CO})$, $143.5(\mathrm{~N}-\mathrm{C}(3) \mathrm{H}-\mathrm{N}), 56.2\left(\mathrm{CH}_{2}\right), 51.8\left(\mathrm{CH}\left(\mathrm{CH}_{3}\right)_{2}\right)$,

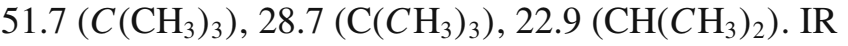
data $\left(\mathrm{cm}^{-1}\right) \mathrm{KBr}$ pellet: 1675 (s) ( $\left.v_{\mathrm{CONH}}\right)$. Anal. Calcd. for $\mathrm{C}_{22} \mathrm{H}_{40} \mathrm{~N}_{8} \mathrm{O}_{2} \mathrm{AgCl} \cdot \mathrm{CH}_{2} \mathrm{Cl}_{2}: \mathrm{C}, 40.81 ; \mathrm{H}, 6.25 ; \mathrm{N}$, 16.55. Found: $\mathrm{C}, 40.82 ; \mathrm{H}, 6.82 ; \mathrm{N}, 16.30 \%$.

\subsection{Transmetallation reaction with gold(I) precursor}

A mixture of $\mathbf{1 b}$ or $\mathbf{2 b}(0.199 \mathrm{mmol}, 1$ eqv. $)$ and $\left(\mathrm{SMe}_{2}\right) \mathrm{AuCl}(0.199 \mathrm{mmol}, 1$ eqv. $)$ in dichloromethane (ca. $25 \mathrm{~mL}$ ), was stirred at room temperature for $3 \mathrm{~h}$ when the formation of an off-white $\mathrm{AgCl}$ precipitate was observed. The reaction mixture was filtered and the solvent was removed under vacuum to give the product $1 \mathrm{c}(0.081 \mathrm{~g}, 62 \%)$ or $2 \mathrm{c}(0.077 \mathrm{~g}, 57 \%)$ as an off white solid. 1c: ${ }^{1} \mathrm{H}$ NMR $\left(\mathrm{CDCl}_{3}, 400 \mathrm{MHz}, 25^{\circ} \mathrm{C}\right)$ : $\delta 8.30(\mathrm{~s}, 2 \mathrm{H}, \mathrm{N}-\mathrm{C}(3) H-\mathrm{N}), 6.19$ (br, $1 \mathrm{H}, \mathrm{NH}), 4.82$ $\left(\mathrm{s}, 4 \mathrm{H}, \mathrm{CH}_{2}\right), 4.40\left(\mathrm{q}, 4 \mathrm{H},{ }^{3} J_{H H}=7 \mathrm{~Hz}, \mathrm{CH}_{2} \mathrm{CH}_{3}\right)$, $1.52\left(\mathrm{t}, 6 \mathrm{H},{ }^{3} J_{H H}=7 \mathrm{~Hz}, \mathrm{CH}_{2} \mathrm{CH}_{3}\right), 1.40(\mathrm{~s}, 18 \mathrm{H}$, $\left.\mathrm{C}\left(\mathrm{CH}_{3}\right)_{3}\right) .2 \mathrm{c}:{ }^{1} \mathrm{H} \mathrm{NMR}\left(\mathrm{CDCl}_{3}, 400 \mathrm{MHz}, 25^{\circ} \mathrm{C}\right): \delta$ 8.97 (br, 2H, NH), 8.41 (s, 2H, N-C(3)H-N), 5.34 (s, $\left.4 \mathrm{H}, \mathrm{CH}_{2}\right), 4.95$ (sept, $\left.2 \mathrm{H},{ }^{3} J_{H H}=7 \mathrm{~Hz}, \mathrm{CH}\left(\mathrm{CH}_{3}\right)_{2}\right)$, $1.60\left(\mathrm{~d}, 12 \mathrm{H},{ }^{3} J_{H H}=7 \mathrm{~Hz}, \mathrm{CH}\left(\mathrm{CH}_{3}\right)_{2}\right), 1.37(\mathrm{~s}, 18 \mathrm{H}$, $\left.\mathrm{C}\left(\mathrm{CH}_{3}\right)_{3}\right)$.

\subsection{Transmetallation reaction with copper(I) precursor}

A mixture of $\mathbf{1 b}$ or $\mathbf{2 b}(0.133 \mathrm{mmol}, 1$ eqv. $)$ and $\left(\mathrm{SMe}_{2}\right) \mathrm{CuBr}(0.133 \mathrm{mmol}, 1$ eqv.) in acetonitrile ( $c$. $20 \mathrm{~mL}$ ), was stirred at room temperature for $3 \mathrm{~h}$. The reaction mixture was filtered and the solvent was removed under vacuum to give the product $1 \mathbf{d}(0.052 \mathrm{~g}$, $69 \%)$ or $\mathbf{2 d}(0.045 \mathrm{~g}, 57 \%)$ as yellowish solid. 1d: ${ }^{1} \mathrm{H}$ NMR $\left(\mathrm{CDCl}_{3}, 400 \mathrm{MHz}, 25^{\circ} \mathrm{C}\right): \delta 8.24(\mathrm{~s}, 2 \mathrm{H}, \mathrm{N}-$ $\mathrm{C}(3) H-\mathrm{N}), 6.80(\mathrm{br}, 2 \mathrm{H}, \mathrm{NH}), 4.89\left(\mathrm{~s}, 4 \mathrm{H}, \mathrm{CH}_{2}\right)$, 4.36 (br, $4 \mathrm{H}, \mathrm{CH}_{2} \mathrm{CH}_{3}$ ), 1.50 (br, $6 \mathrm{H}, \mathrm{CH}_{2} \mathrm{CH}_{3}$ ), 1.37 (s, $\left.18 \mathrm{H}, \mathrm{C}\left(\mathrm{CH}_{3}\right)_{3}\right) .2 \mathrm{~d}:{ }^{1} \mathrm{H}$ NMR $\left(\mathrm{CDCl}_{3}, 400 \mathrm{MHz}\right.$, $\left.25^{\circ} \mathrm{C}\right): \delta 8.27$ (s, $\left.2 \mathrm{H}, \mathrm{N}-\mathrm{C}(3) H-\mathrm{N}\right), 6.50(\mathrm{br}, 2 \mathrm{H}, \mathrm{NH}$ ), 4.98 (s, 4H, CH$\left.H_{2}\right), 4.85$ (br, 2H, $\left.\mathrm{CH}\left(\mathrm{CH}_{3}\right)_{2}\right), 1.53$ (br, $\left.12 \mathrm{H}, \mathrm{CH}\left(\mathrm{CH}_{3}\right)_{2}\right), 1.39$ (s, $\left.18 \mathrm{H}, \mathrm{C}\left(\mathrm{CH}_{3}\right)_{3}\right)$.

\section{Computational methods}

The density functional theory calculations were performed on the following cationic silver (I) $\left\{(\mathrm{NHC})_{2} \mathrm{Ag}\right\}^{+}$type species, 1b' and $\mathbf{2 b}$ ' using GAUSSIAN $03^{18}$ suite of quantum chemical programs. The Becke three-parameter exchange functional in conjunction with Lee-Yang-Parr correlation functional (B3LYP) has been employed in this study. ${ }^{19}$ StuttgartDresden effective core potential (ECP), representing 19 core electrons, along with valence basis set, SDD is used for silver ${ }^{20}$ and all other atoms are treated with 6-31G(d) basis set. ${ }^{21}$ All stationary points are characterized as minima by evaluating Hessian indices on the respective potential energy surfaces. Tight SCF convergence $\left(10^{-8}\right.$ a.u. $)$ was used for all calculations. Natural Bond Orbital (NBO) analysis ${ }^{22}$ was performed using the NBO 3.1 program implemented in the GAUSSIAN 03 package. 
Inspection of the metal-ligand, donor-acceptor interactions was carried out using the Charge Decomposition Analysis (CDA). ${ }^{23} \mathrm{CDA}$ is a valuable tool in analysing the interactions between molecular fragments on a quantitative basis, with an emphasis on the electron donation. ${ }^{24}$ The orbital contributions in the geometry optimized silver(I) $\left\{(\mathrm{NHC})_{2} \mathrm{Ag}\right\}^{+}$type species, $\mathbf{1 b}$ ' and $\mathbf{2} \mathbf{b}$ ' can be divided into three parts:

(i) $\sigma$-donation from the $[\mathrm{NHC} \rightarrow \mathrm{Ag}]$ fragment

(ii) $\pi$-back donation from $[\mathrm{NHC} \leftarrow \mathrm{Ag}]$ fragment and

(iii) repulsive polarization $(r)$.

The CDA calculations are performed using the program AOMix ${ }^{25}$ using the B3LYP/SDD, 6-31G(d) wave function for $\mathbf{1} \mathbf{b}^{\prime}$ and $\mathbf{2} \mathbf{b}^{\prime}$. Molecular orbital (MO) compositions and the overlap populations were calculated using the AOMix Program. The analysis of the MO compositions in terms of occupied and unoccupied fragment orbitals (OFOs and UFOs, respectively), construction of orbital interaction diagrams, the charge decomposition analysis (CDA) was performed using the AOMix-CDA. ${ }^{26}$

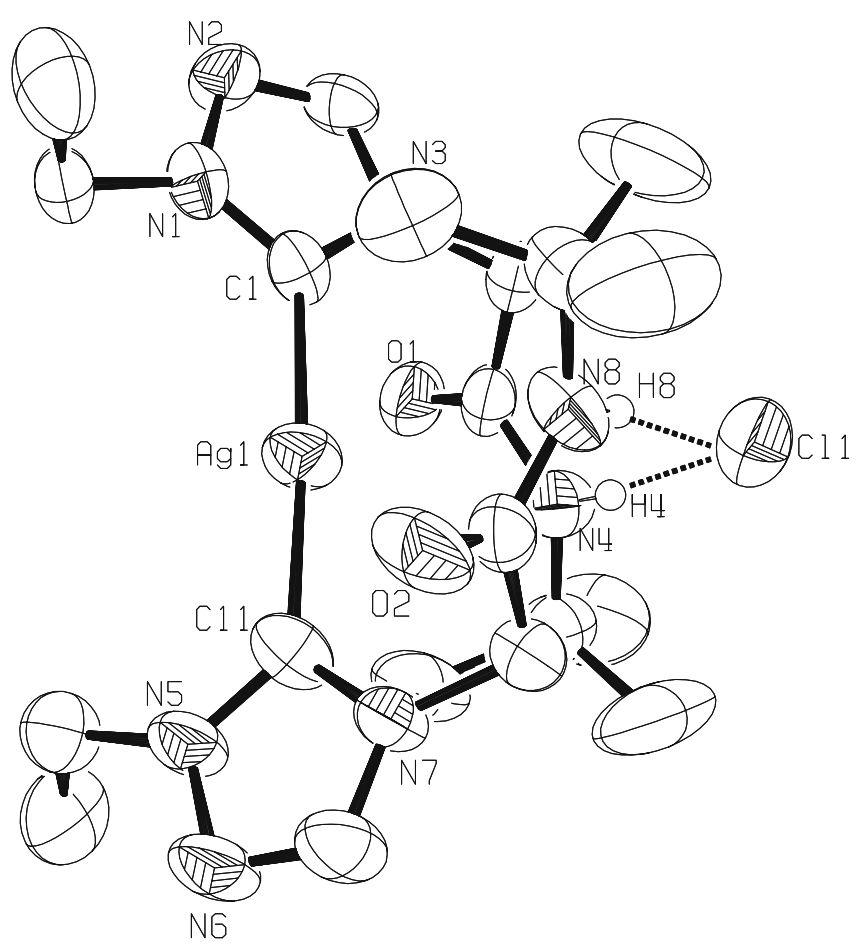

Figure 2. ORTEP drawing of $\mathbf{1 b}$ with thermal ellipsoids shown at the $50 \%$ probability level. Selected bond lengths $(\AA)$ and angles $\left(^{\circ}\right)$ : Ag1-C1 2.081(9), Ag1-C11 2.072(9), N1-C1 1.329(11), N3-C1 1.344(9), N5-C11 1.330(11), N7-C11 1.341(11), C1-Ag1-C11 176.5(3), N1-C1-N3 103.5(7), N5-C11-N7 102.8(7).

\section{Results and discussion}

Two new $N / O$-functionalized 1,2,4-triazole-based $\mathrm{N}$-heterocyclic carbenes namely, 1-R-4- $(N-t$ butylacetamido)-1,2,4-triazol-5-ylidene [R $=\mathrm{Et}, i$-Pr] were designed for studying its transition metal chemistry and in this regard, we sought to synthesize first its silver complexes as these are known for their transmetallation ability for synthesizing other metal complexes. Specifically, the carbene precursors i.e., the 1,2,4-triazolium chloride salts, $\mathbf{1 a}$ and $\mathbf{2 a}$, were synthesized by the alkylation reaction of 1-R-1,2,4-triazole $(\mathrm{R}=\mathrm{Et}, i$-Pr) with $N$-t-butyl-2-chloro acetamide in $47-63 \%$ yield (scheme 1). The formations of the 1a and 2a were evident from the appearances of a high downfield shifted peak at $10.7-10.9 \mathrm{ppm}$ in ${ }^{1} \mathrm{H}$ NMR spectrum that corresponded to the $\mathrm{NC}(5) H \mathrm{~N}$ resonance. The same appeared at 144.7-145.0 ppm in the ${ }^{13} \mathrm{C}\{\mathrm{H}\}$ NMR spectrum. The amide(-CONH) moiety for 1a and 2a appeared at $1682 \mathrm{~cm}^{-1}$ in the infrared spectrum, slightly shifted from the starting precursor $N$-t-butyl-2-chloro acetamide that appeared at $1685 \mathrm{~cm}^{-1}$.

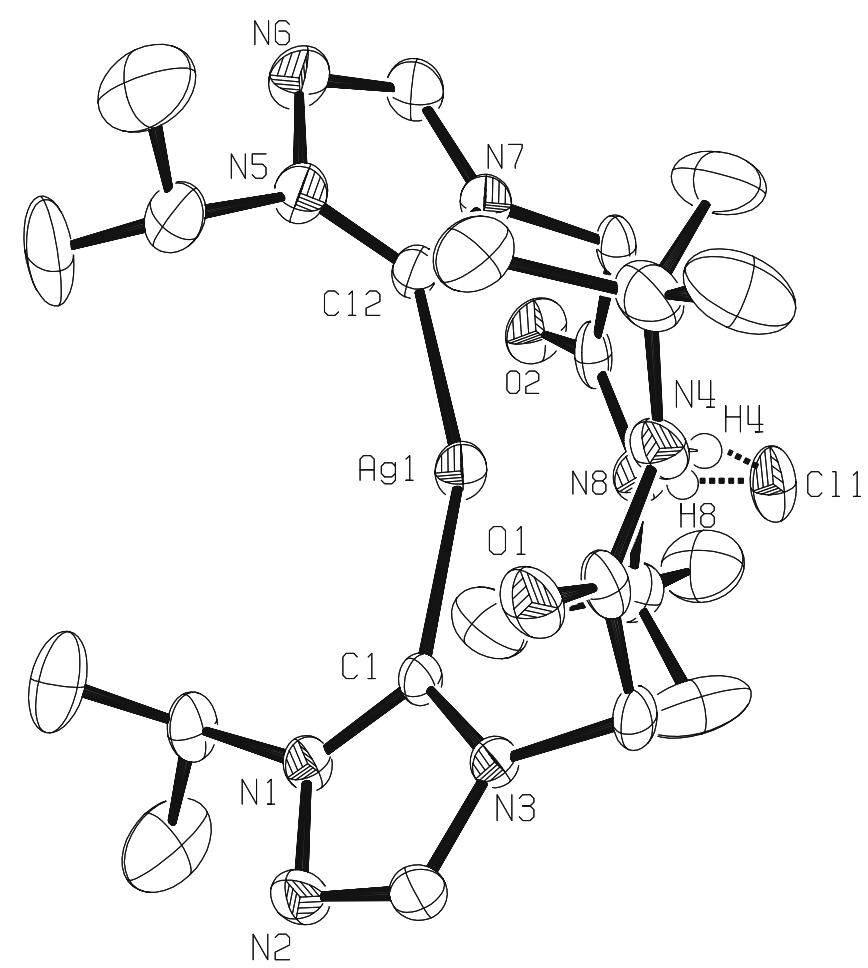

Figure 3. ORTEP drawing of $\mathbf{2 b}$ with thermal ellipsoids shown at the $50 \%$ probability level. Selected bond lengths $(\AA)$ and angles $\left({ }^{\circ}\right)$ : Ag1-C1 2.103(4), Ag1C12 2.106(5), N1-C1 1.325(6), N3-C1 1.360(5), N5-C12 1.320(6), N7-C12 1.352(6), C1-Ag1-C12 157.91(16), N1C1-N3 102.4(4), N5-C12-N7 102.6(4). 


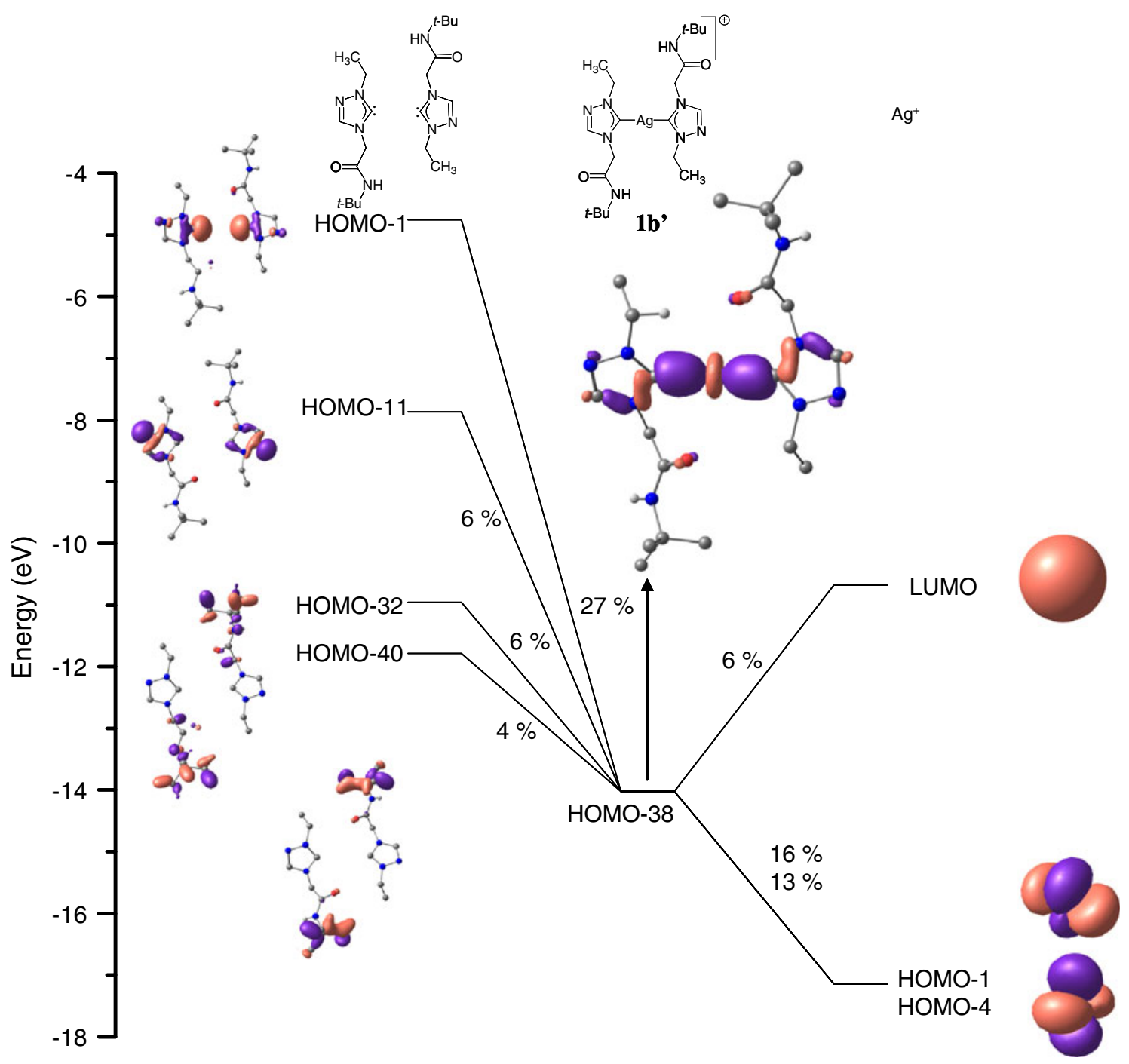

Figure 4. Simplified orbital interaction diagram showing the major contributions of the NHC-silver bond in $\mathbf{1 b}$.

The silver complexes $\mathbf{1 b}$ and $\mathbf{2} \mathbf{b}$ were synthesized by the direct reaction of 1,2,4-triazolium chloride salts $1 \mathrm{a}$ and 2a with $\mathrm{Ag}_{2} \mathrm{O}$ in $53-56 \%$ yield (figure 1 and scheme 1). As expectedly, the ${ }^{13} \mathrm{C}$ NMR of the silver $\mathbf{1 b}$ and $\mathbf{2 b}$ complexes showed highly downfield shift peak at $180.7-181.7 \mathrm{ppm}$ characteristic of a $\mathrm{C}_{\text {carbene }}-\mathrm{Ag}$ resonance thereby suggesting the formation of the silver complexes.

The molecular structures of the silver $\mathbf{1 b}$ and $\mathbf{2 b}$ complexes as determined by $\mathrm{X}$-ray diffraction studies showed $\mathbf{1 b}$ and $\mathbf{2 b}$ to be discrete monomeric $\left\{(\mathrm{NHC})_{2} \mathrm{Ag}\right\}^{+} \mathrm{Cl}^{-}$type complexes displaying linear geometry at silver $\left[\angle \mathrm{C} 1-\mathrm{Ag} 1-\mathrm{C} 11 \quad 176.5(3)^{\circ}(\mathbf{1 b})\right.$, $\angle \mathrm{C} 1-\mathrm{Ag} 1-\mathrm{C} 12$ 157.91(16) ${ }^{\circ}$ (2b)] (figures 2 and 3). In this regard, it is worth noting that the corresponding imidazole analogues of $\mathbf{2 b}$ exhibited similar $\left\{(\mathrm{NHC})_{2} \mathrm{Ag}\right\}^{+} \mathrm{Cl}^{-}$type structures. ${ }^{6 \mathrm{~b}}$ The $\mathrm{C}_{\text {carbene }}-\mathrm{Ag}$ bond distances in $\mathbf{1 b}[2.081(9), 2.072(9) \AA]$ and 2b $[2.103(4), 2.106(5) \AA]$ are slightly shorter than sum of individual covalent radii of $\mathrm{Ag}$ and C $(2.111 \AA)^{27}$ and are comparable to that of an imidazole analogue namely, \{[1-( $i$-propyl $)-3-$ $\left.\{\mathrm{N} \text { - }(t \text {-butylacetamido)imidazol-2-ylidene }\}]_{2} \mathrm{Ag}\right\}^{+} \mathrm{Cl}^{-}$ $[2.087(4) \AA] .{ }^{6 \mathrm{~b}}$ Another interesting feature of the $\mathbf{1 b}$ and $\mathbf{2 b}$ structures is that the chloride anion was seen bridging by two hydrogen bonding interaction to the amide- $\mathrm{N} H$ protons of the functionalized sidearms displaying $[\mathrm{N}-\mathrm{H} \cdots \mathrm{Cl}]$ distances of 3.19$3.22 \AA$ which are less than the sum of van der Waals radii of $\mathrm{N}$ and $\mathrm{Cl}(3.30 \AA) .{ }^{28}$ Interestingly, the imidazole analogous of $\mathbf{2} \mathbf{b}$, the $\{[1-(i$-propyl)-3$\{N$-( $t$-butylacetamido)imidazol-2-ylidene $\left.\}]_{2} \mathrm{Ag}\right\}^{+} \mathrm{Cl}^{-}$ complexes showed similar hydrogen bonding interaction between the chloride anion with the amide- $\mathrm{NH}$ 


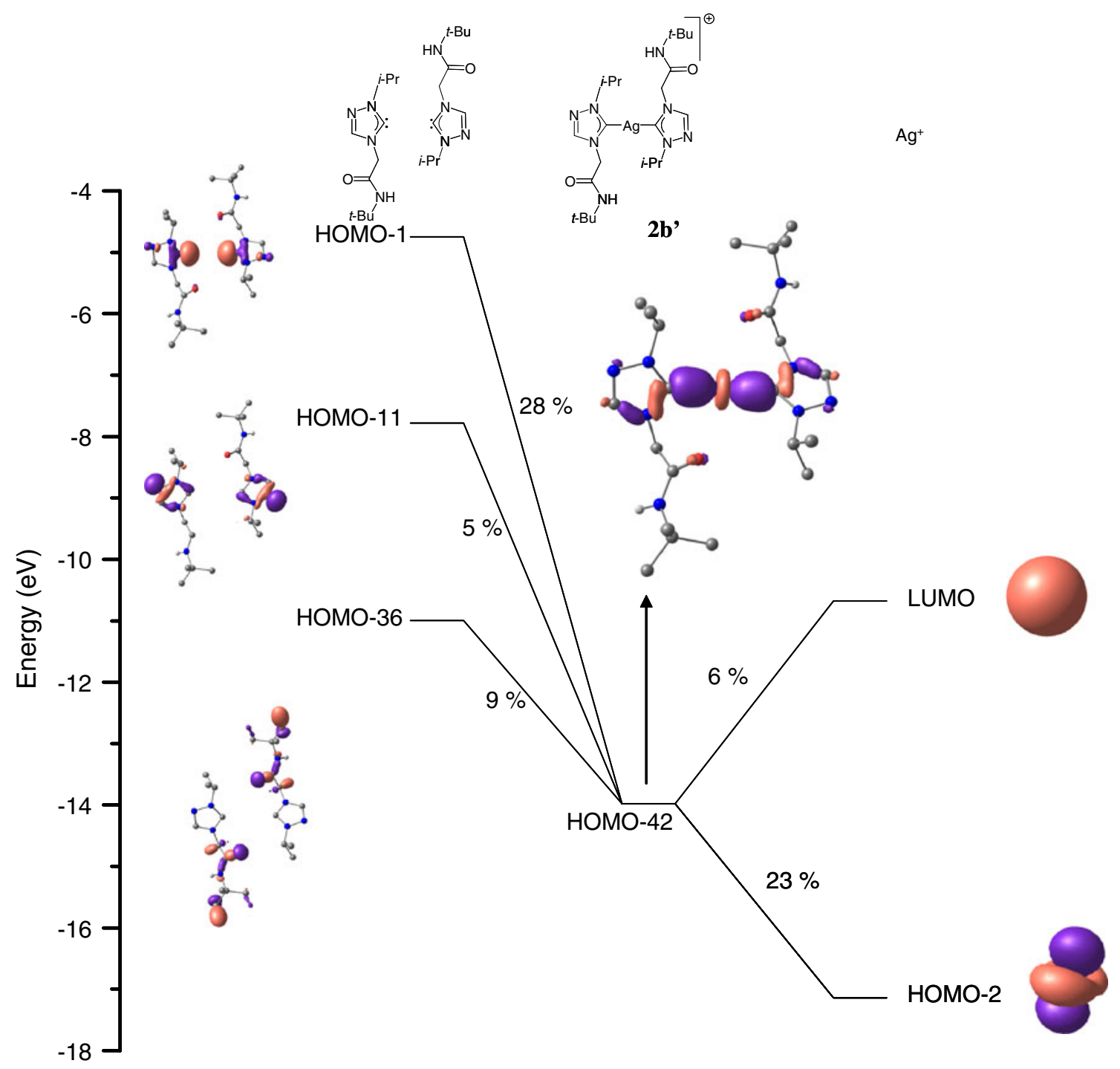

Figure 5. Simplified orbital interaction diagram showing the major contributions of the NHC-silver bond in $\mathbf{2 b}$.

protons of the two functinalized sidearms. ${ }^{6 b}$ Further support in favour of the $[\mathrm{N}-\mathrm{H} \cdots \mathrm{Cl}]$ hydrogen bonding interaction came from the infrared spectrum in which the bridging - $\mathrm{CONH}$ moiety appeared at 1674 $1675 \mathrm{~cm}^{-1}$ at a $(\Delta v) 10-11 \mathrm{~cm}^{-1}$ red shifted from that of $\mathrm{N}$ - $t$-butyl-2-chloro acetamide $\left(1685 \mathrm{~cm}^{-1}\right)$ devoid of any such hydrogen bonding interaction.

Another interesting aspect of the $\mathbf{1 b}$ and $\mathbf{2 b}$ structures is that the two 1,2,4-triazole rings were found to be non-coplanar [ $\angle \mathrm{N} 1-\mathrm{C} 1-\mathrm{Ag} 1-\mathrm{C} 11-\mathrm{N} 7138.0^{\circ}$ (1b), $\left[\angle \mathrm{N} 1-\mathrm{C} 1-\mathrm{Ag} 1-\mathrm{C} 12-\mathrm{N} 7113.9^{\circ}\right.$ (2b)] similar to what had been observed in case of the imidazole analog $\{[1$ - ( $i$ - propyl) - $3-\{N$ - ( $t$-butylacetamido) imidazol-2ylidene $\left.\}]_{2} \mathrm{Ag}\right\}^{+} \mathrm{Cl}^{-}\left[\angle \mathrm{N} 2-\mathrm{C} 1-\mathrm{Ag} 1-\mathrm{C} 1-\mathrm{N} 1122.9^{\circ}\right] .{ }^{6 \mathrm{~b}}$ In this regard it is worth mentioning that both coplanar and non-coplanar structures have been reported for
$\left\{(\mathrm{NHC})_{2} \mathrm{Ag}\right\}^{+} \mathrm{X}^{-}(\mathrm{X}=$ halide $)$ type complexes. ${ }^{6 \mathrm{~b}, 12 \mathrm{~d}}$ Significantly enough, unlike that of the silver complexes of imidazole-based $\mathrm{N}$-heterocyclic carbenes for which numerous complexes have been structurally characterized, such examples of the silver complexes of 1,2,4-triazole-based N-heterocyclic carbenes are extremely rare. We are aware of only two reports of structurally characterized silver 1,2,4triazole based $\mathrm{N}$-heterocyclic carbene complexes namely, [\{(1,2-di-methyl-4-( $i$-propyl)-1,2,4-triazol3,5-diylidene) $\left.\mathrm{Ag}\}^{+} \mathrm{TfO}^{-}\right]_{\mathrm{n}}{ }^{29}$ and $\{[1,2,4$-tri-methyl1,2,4-triazol-5-ylidene $\left.]_{2}^{2+} \mathrm{Ag}\right\}^{+} 3\left(\mathrm{TfO}^{-}\right) .{ }^{30}$

In order to gain insight into the nature of the NHC$\mathrm{Ag}$ interaction in the $\mathbf{1 b}$ and $\mathbf{2} \mathbf{b}$ complexes, the density functional theory (DFT) study were carried out by computing the geometry optimized structures (1)' and $\mathbf{2} \mathbf{b}^{\mathbf{}}$ ) 
of the silver $\mathbf{1 b}$ and $\mathbf{2 b}$ complexes at B3LYP/SDD, 6$31 \mathrm{G}(\mathrm{d})$ level of theory, followed by single point calculations performed at the same level of theory (supporting information tables S1-S2). The Natural Bond Orbital (NBO) calculations were performed on these computed structures for better understanding of the electronic properties of these complexes. The strong $\sigma$-donating ability of the N-heterocyclic carbene ligand to the metal center was reflected in the Mulliken and natural charge analyses that showed the metal center becomingelectron-rich upon binding to the N-heterocyclic carbene ligand fragment concomitant with the loss of the electron density at the free NHC fragment compared to its bonded form in $\mathbf{1} \mathbf{b}$ ' and $\mathbf{2 b}$ ' (supporting information tables S3-S4). Further scrutiny of the electronic configuration showed that the electron donation from the NHC fragments occurred onto the $5 s$ orbital of silver in the 1b' and $\mathbf{2} \mathbf{b}$ ' complexes (supporting information table S5).

A careful analysis of the NBO results further indicated that the $\mathrm{Ag}-\mathrm{C}_{\text {carbene }}$ bond in $\mathbf{1} \mathbf{b}^{\prime}$ and $\mathbf{2} \mathbf{b}$ ' is composed of an interaction between a $\mathrm{C}_{s p}^{2}$ orbital of the 1,2,4-triazole-based NHC ligand with a $s d$ orbital of the silver (supporting information table S6).

The Charge Decomposition Analysis (CDA) studies were performed on $\mathbf{1} \mathbf{b}$ ' and $\mathbf{2} \mathbf{b}$ ' using the AOMix-CDA software, to estimate the relative extent of the NHC $\stackrel{\sigma}{\longrightarrow} \mathrm{Ag} \sigma$-donation $(d)$ and NHC $\stackrel{\pi}{\longleftarrow} \mathrm{Ag} \pi$-back donation $(b)$ occurring in these complexes. The charge decomposition analysis (CDA) study showed that the 1,2,4-triazole-based $\mathrm{N}$-heterocyclic carbenes are good $\sigma$-donating ligands that exhibit high $d / b$ ratios in the range 12.35-12.50, similar to that seen in the imidazole-based silver $\mathrm{N}$-heterocyclic carbene complexes namely, $\{[1-$ ( $i$-propyl)-3- $\{N$-( $t$-butylacetamido)imidazol-2ylidene $\left.\}]_{2} \mathrm{Ag}\right\}^{+} \mathrm{Cl}^{-} \quad[11.44]^{6 \mathrm{~b}}$ and $\{[1-(t$-butyl)-3$\{N$-( $t$-butylacetamido)imidazol-2 - ylidene $\left.\}]_{2} \mathrm{Ag}\right\}^{+} \mathrm{Cl}^{-}$ $[12.53]^{6 \mathrm{~b}}$ (supporting information table $\mathrm{S} 7$ ).

The NHC-Ag interaction of 1,2,4-triazole-based $\mathrm{N}$-heterocyclic carbene was further probed by constructing the molecular orbital (MO) correlation diagram from the individual fragment molecular orbitals (FMOs) of the 1,2,4-triazole-based N-heterocyclic carbene ligand fragment with that of the silver fragment. The particular interests are NHC-Ag $\sigma$-bonding molecular orbitals that are represented by HOMO-38 (1)') and HOMO-42 (2b') in the silver complexes (figures 4-5 and supporting information figures S1$\mathrm{S} 2)$. It is worth noting that the NHC-Ag $\sigma$-orbital are deeply buried thereby pointing towards the greater stability of the NHC-Ag interactions. Lastly, the bond dissociation energy $(\mathrm{De})$ of the $\mathrm{NHC}-\mathrm{Ag}$ interaction in 1b' $[88.2 \mathrm{kcal} / \mathrm{mol}$ ] and $\mathbf{2 b}$ ' $[88.6 \mathrm{kcal} / \mathrm{mol}$ ] were computed at B3LYP/SDD, 6-31G(d) level of theory and the values suggested strong interaction between the silver and the 1,2,4-triazole-based N-heterocyclic carbene ligand fragments in $\mathbf{1 b}$ ' and $\mathbf{2 b}$ ' (supporting information table S8).

The reactivity studies of silver(I) complexes, $\mathbf{1 b}$ and $\mathbf{2 b}$, showed them to be good transmetallating agents as the clean formations of the corresponding gold(I) complexes $\{[1-\mathrm{R}-4-(N$ - $t$-butylacetamido)-1,2,4-triazol5-ylidene ${ }_{2} \mathrm{Au}^{+}{ }^{+} \mathrm{Cl}^{-}[\mathrm{R}=\mathrm{Et}(\mathbf{1 c}), i$-Pr $(\mathbf{2 c})]$, were seen when treated with $\left(\mathrm{SMe}_{2}\right) \mathrm{AuCl}$ in $57-62 \%$ yield. Similarly, the reaction of $\mathbf{1 b}$ and $\mathbf{2 b}$ with $\left(\mathrm{SMe}_{2}\right) \mathrm{CuBr}$ gave the corresponding copper(I) complexes $\{[1-\mathrm{R}-4$ ( $N$ - $t$-butylacetamido)-1,2,4-triazol-5-ylidene $]_{2} \mathrm{Cu}^{+}{ }^{+} \mathrm{Br}^{-}$ $[\mathrm{R}=\mathrm{Et}(\mathbf{1 d}), i-\operatorname{Pr}(\mathbf{2 d})]$ in 57-69\% yield (scheme 2).

\section{Conclusion}

In summary, a series of new silver $\mathbf{1 b}$ and $\mathbf{2} \mathbf{b}$ complexes supported over 1,2,4-triazole-based $N$-functionalized $\mathrm{N}$-heterocyclic carbene ligands have been synthesized. The molecular structures of the silver, $\mathbf{1 b}$ and $\mathbf{2} \mathbf{b}$, complexes as determined by the $\mathrm{X}$-ray diffraction studies, revealed these to be $\left\{(\mathrm{NHC})_{2} \mathrm{Ag}\right\}^{+} \mathrm{Cl}^{-}$type complexes displaying linear geometry at metal center. The density functional theory (DFT) studies further suggested that the 1,2,4-triazole-based $\mathrm{N}$-heterocyclic carbenes are good $\sigma$-donating ligands with very little $\pi$-back bonding ability. The reactivity studies with $\left(\mathrm{SMe}_{2}\right) \mathrm{AuCl}$ and $\left(\mathrm{SMe}_{2}\right) \mathrm{CuBr}$ showed that the silver $\mathbf{1 b}$ and $\mathbf{2 b}$ complexes to be good transmetallating agents.

\section{Supplementary information}

CCDC-727835 (1b) and CCDC-675427 (2b) contain the supplementary crystallographic data for this paper. The data can be obtained free of charge at www.ccdc.cam.ac.uk/conts/retrieving.html or [from the Cambridge Crystallographic Data Center, 12 Union Road, Cambridge CB2 1EZ, UK; Fax: (internat.) +44-1223/336-033; E-mail: deposit@ccdc.cam.ac.uk]. The B3LYP coordinates of the optimized geometries for 1b' and 2b', NBO tables and CDA table along with orbital interaction diagrams of $\mathbf{1 b}$ ' and $\mathbf{2 b}$ '. This material can be seen in the Academy website http://www.ias.ac.in/chemsci. 


\section{Acknowledgements}

PG thanks Board of Research in Nuclear Sciences, Mumbai, for financial support of this research. PG is grateful to the National Single Crystal X-ray Diffraction Facility and Sophisticated Analytical Instrument Facility at IIT Bombay, India, for the crystallographic and other characterization data. Computational facilities from the IIT Bombay Computer Center are gratefully acknowledged. CKD thanks Council of Scientific and Industrial Research (CSIR) and University Grants Commission (UGC), New Delhi, for research fellowship.

\section{References}

1. (a) Pugh D and Danopoulos A A 2007 Coord. Chem. Rev. 251 610; (b) Crudden C M and Allen D P 2004 Coord. Chem. Rev. 248 2247; (c) Peris E and Crabtree R H 2004 Coord. Chem. Rev. 248 2239; (d) Herrmann W A 2002 Angew. Chem. Int. Ed. 411290

2. Yen S K, Koh L L, Hahn F E, Huynh H V and Hor T S A 2006 Organometallics 255105

3. (a) Zanardi A, Mata J A and Peris E 2009 Organometallics 28 4335; (b) Ros A, Alcarazo M, Iglesias-Sigüenza J, Díez E, Álvarez E, Fernández R and Lassaletta J M 2008 Organometallics 27 4555; (c) Gnanamgari D, Moores A, Rajaseelan E and Crabtree R H 2007 Organometallics 261226

4. Mathew P, Neels A and Albrecht M 2008 J. Am. Chem. Soc. 13013534

5. Schütz J, Herdtweck E and Herrmann W A 2004 Organometallics 236084

6. (a) Samantaray M K, Pang K, Shaikh M M and Ghosh P 2008 Dalton Trans. 4893; (b) Samantaray M K, Pang K, Shaikh M M and Ghosh P 2008 Inorg. Chem. 47 4153; (c) Ray L, Shaikh M M and Ghosh P 2008 Inorg. Chem. 47 230; (d) Samantaray M K, Roy D, Patra A, Stephen R, Saikh M, Sunoj R B and Ghosh P 2006 J. Organomet. Chem. 6913797

7. (a) John A and Ghosh P 2010 Dalton Trans. 397183 ; (b) Ray S, Mohan R, Singh J K, Samantaray M K, Shaikh M M, Panda D and Ghosh P 2007 J. Am. Chem. Soc. 129 15042; (c) Ray S, Asthana J, Tanski J M, Shaikh M M, Panda D and Ghosh P 2009 J. Organomet. Chem. 6942328

8. (a) Kumar S, Shaikh M M and Ghosh P $2009 J$. Organomet. Chem. 694 4162; (b) Ray L, Shaikh M M, and Ghosh P 2007 Organometallics 26 958; (c) Ray L, Shaikh M M, Ghosh P 2007 Dalton Trans. 4546

9. Dash C, Shaikh M M and Ghosh P 2009 Eur. J. Inorg. Chem. 1608

10. (a) John A, Shaikh M M and Ghosh P 2009 Dalton Trans. 10581; (b) Samantaray M K; Shaikh M M and Ghosh P 2009 J. Organomet. Chem. 694 3477; (b) Ray L, Barman S, Shaikh M M and Ghosh P 2008 Chem. Eur. J. 146646

11. (a) Samantaray M K, Shaikh M M and Ghosh P 2009 Organometallics 28 2267; (b) Ray S, Shaikh M M and Ghosh P 2009 Eur. J. Inorg. Chem. 1932

12. (a) Ray L, Katiyar V, Barman S; Raihan M J, Nanavati H, Shaikh M M and Ghosh P 2007 J. Organomet. Chem. 692 4259; (b) Samantaray M K, Katiyar V, Pang K, Nanavati H and Ghosh P 2007 J. Organomet. Chem. 692 1672; (c) Ray L, Katiyar V, Raihan M J, Nanavati H, Shaikh M M and Ghosh P 2006 Eur. J. Inorg. Chem. 3724; (d) Samantaray M K, Katiyar V, Roy D, Pang K, Nanavati H, Stephen R, Sunoj R B and Ghosh P 2006 Eur. J. Inorg. Chem. 2975

13. Dallacker F and Minn K 1986 Chemiker-Zeitung 110 101

14. Bulger P G, Cottrell I F, Cowden C J, Davies A J and Dolling U-H 2000 Tetrahedron Lett. 41 1297

15. Brandys M-C, Jennings M C and Puddephatt R J 2000 J. Chem. Soc., Dalton Trans. 4601

16. Kiyotsuka Y, Acharya H P, Katayama Y, Hyodo T and Kobayashi Y 2008 Org. Lett. 101719

17. (a) Sheldrick G M 1997 SHELXL-97, Program for refinement of crystal structures (Germany: University of Gottingen); (b) Sheldrick G M 1997 SHELXS-97, Structure solving program (Germany: University of Gottingen)

18. Frisch M J, Trucks G W, Schlegel H B, Scuseria G E, Robb M A, Cheeseman J R, Montgomery J A Jr, Vreven T, Kudin K N, Burant J C, Millam J M, Iyengar S S, Tomasi J, Barone V, Mennucci B, Cossi M, Scalmani G, Rega N, Petersson G A, Nakatsuji H, Hada M, Ehara M, Toyota K, Fukuda R, Hasegawa J, Ishida M, Nakajima T, Honda Y, Kitao O, Nakai H, Klene M, Li X, Knox J E, Hratchian H P, Cross J B, Adamo C, Jaramillo J, Gomperts R, Stratmann R E, Yazyev O, Austin A J, Cammi R, Pomelli C, Ochterski J W, Ayala P Y, Morokuma K, Voth G A, Salvador P, Dannenberg J J, Zakrzewski V G, Dapprich S, Daniels A D, Strain M C, Farkas O, Malick D K, Rabuck A D, Raghavachari K, Foresman J B, Ortiz J V, Cui Q, Baboul A G, Clifford S, Cioslowski J, Stefanov B B, Liu G, Liashenko A, Piskorz P, Komaromi I, Martin R L, Fox D J, Keith T, Al-Laham M A, Peng C Y, Nanayakkara A, Challacombe M, Gill P M W, Johnson B, Chen W, Wong M W, Gonzalez C and Pople J A 2004 GAUSSIAN 03: Gaussian 03, Revision C.02, Gaussian, Inc., (Wallingford, CT)

19. Becke A D 1988 Phys. Rev. A 383098

20. (a) Alkauskas A, Baratoff A and Bruder C 2004 J. Phys. Chem. A 108 6863; (b) Andrae D, Häussermann U, Dolg M, Stoll H and Preuß H 1990 Theor. Chim. Acta 77123

21. Hehre W J, Ditchfield R and Pople J A 1972 J. Chem. Phys. 562257

22. Reed A E, Curtiss L A and Wienhold F 1988 Chem. Rev. 88899

23. Dapprich S and Frenking G 1995 J. Phys. Chem. 99 9352 
24. (a) Vyboishchikov S F and Frenking G 1998 Chem. Eur J. 84 1439; (b) Frenking G and Pidun U 1997 J. Chem. Soc., Dalton Trans. 1653

25. Gorelsky S I 1997 AOMix: Program for molecular orbital analysis. (Toronto, Canada: York University); http://www.sg-chem.net/ (accessed June 27, 2009)

26. Gorelsky S I, Ghosh S and Solomon E I 2006 J. Am. Chem. Soc. 128278
27. Pauling L 1960 The nature of the chemical bond (Ithaca, NY: Cornell University Press) 3rd edn, p 224-228, 256258

28. Bondi A 1964 J. Phys. Chem. 68441

29. Guerret O, Solé S, Gornitzka H, Teichert M, Trinquier G and Bertrand G 1997 J. Am. Chem. Soc. 1196668

30. Guerret O, Solé S, Gornitzka H, Trinquier $\mathrm{G}$ and Bertrand G 2000 J. Organomet. Chem. 600112 